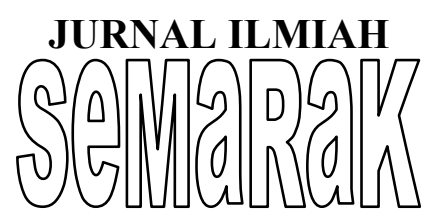

P-ISSN 2615-6849, E-ISSN 2622-3686

Jurnal Semarak,Vol. 1,No.3,Oktober 2018, Hal (49-61)

@ Prodi Manajemen Fakultas Ekonomi Universitas Pamulang

\title{
ANALISIS TINGKAT RESIKO HARGA SAHAM SEKTOR TELEKOMUNIKASI DI BURSA EFEK INDONESIA
}

TAHUN $2016-2018$

\author{
(Study Kasus: Telkom dan Indosat) \\ Thaharuddin \\ Dosen02091@unpam.ac.id
}

\begin{abstract}
ABSTRAK
Penelitian ini bertujuan untuk mengetahui besar/kecilnya tingkat resiko harga saham PT. Telekomunikasi Indonesia, Tbk (TLKM) dan PT. Indosat,Tbk di Bursa Efek Indonesia selama periode tersebut, yang kiranya dapat dijadikan sebagai acuan bagi investor untuk berinvestasi pada kedua saham tersebut.

Rumus yang saya gunakan dalam menganalisis tingkat resiko adalah Standar Deviasi dengan variabel independen Indeks Harga Saham Individual(IHSI) penutupan akhir bulan dan Beta( $\beta$ ) saham dengan variabel independen Indeks Harga Saham Gabungan (IHSG)) penutupan akhir bulan dan Harga Saham penutupan akhir bulan.

Penelitian ini saya bagi ke dalam 2 masa (periode), yaitu periode I: Januari 2016 - April 2017 dan periode II: Mei 2017- Agustus 2018(masa terjadinya pelemahan nilai mata uang Rupiah terhadap Dollar Amerika)

Dari hasil analisis dengan menggunakan Standar Deviasi, akan dapat diketahui tingkat resiko harga saham periode mana yang lebih rendah, lebih aman bagi investor dalam berinvesttasi saham. Sedangkan dari hasil analisis dengan $\operatorname{Beta}(\beta)$ saham, akan dapat diketahui pada periode mana saham mempunyai koefisien $\operatorname{Beta}(\beta)$ rendah yang lebih aman bagi investor dalam berinvestasi saham.
\end{abstract}

\section{Kata Kunci: Resiko, Investasi, Saham}

\section{ABSTRACT}

This study aims to determine the level of risk of the stock price of PT. Telekomunikasi Indonesia, Tbk (TLKM) and PT. Indosat, Tbk on the Indonesia Stock Exchange during this period, which may be used as a reference for investors to invest in both shares

The formula that I use in analyzing the level of risk is the Standard Deviation with the independent variable Individual Stock Price Index (IHSI) at the end of the month and Beta ( $\beta$ ) shares with the independent variable Composite Stock Price Index (IHSG) closing month end and Stock Price closing at the end of the month. 


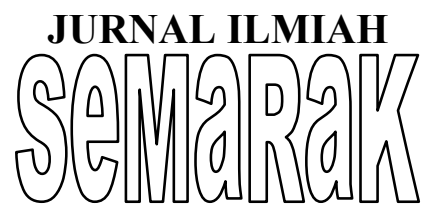

\author{
P-ISSN 2615-6849, E-ISSN 2622-3686 \\ Jurnal Semarak,Vol. 1,No.3,Oktober 2018 , Hal (49-61) \\ @Prodi Manajemen Fakultas Ekonomi Universitas Pamulang
}

This research is divided into 2 periods (periods), namely period I: January 2016 - April 2017 and period II: May 2017 - August 2018 (the period of the weakening value of the Rupiah against the US Dollar)

From the results of the analysis using Standard Deviation, it will be able to know which level of stock price risk is lower, safer for investors to invest in shares. While the results of the analysis with Beta ( $\beta$ ) shares, will be known in the period where the stock has a low Beta ( $\beta$ ) coefficient which is safer for investors in investing in shares.

\title{
Keywords: Risk, Investment, Shares
}

\section{PENDAHULUAN}

\section{A. Latar Belakang}

Tujuan yang paling mendasar dari investor membeli saham adalah mengharapkan keuntungan baik dari "dividen" maupun dari "kenaikan harga" saham yang diperdagangkan di Bursa Efek berupa "Capital Gain" yang diperoleh dari kenaikan kurs saham yang dibelinya. Harga saham yang bersedia dibeli oleh investor mencerminkan arus Kas Bersih yang diharapkan setelah memperhitungkan waktu dan resiko investasi. Jika resiko dari Pasar Modal besar, maka hasil pengembalian yang diharapkan dari investasinya besar pula. Sebaliknya bila resiko investasinya kecil, maka hasil yang diharapkan dari investasinya kecil pula.

Di Pasar Modal resiko investasi adalah Fluktuasi Harga. Harga tersebut dipengaruhi oleh kondisi Makro Ekonomi seperti: inflasi, tingkat suku bunga perbankan, angka pertumbuhan ekonomi, Neraca Perdagangan serta kekuatan permintaan dan penawaran dalam perdagangan saham.
Resiko-resiko umum lainnya yang dapat mempengaruhi perubahan harga saham diantaranya:

Resiko Politik dan Hukum. Berbagai kebijakan politik dan hukum yang dilakukan atau ditetapkan oleh Pemerintah seperti perubahan Undang-undang, kebijakankebijakan dan Peraturan-peraturan yang berkaitan dengan dunia usaha seperti: kebijakan Ekspor -Impor, kebijakan Pajak dan Tarif.

Resiko Fluktuasi Nilai Tukar Mata Uang Asing. Harga saham akan ikut berubah sehubungan dengan menguat/melemahnya nilai tukar rupiah terhadap mata uang asing. Hal ini terkait dengan bahan baku dari produk hasil industri perusahaan,khususnya bahan bakunya impor, pinjaman perusahaan dari Lembaga Keuangan Internasional dalam bentuk mata uang asing.

Resiko Perubahan Kondisi Perusahaan. Hal ini dapat terjadi dalam internal perusahaan seperti kerusakan pabrik, kebakaran pabril, kekurangan bahan baku, pemogokan karyawan yang berlarut-larut yang berakibat terganggunya produksi. 


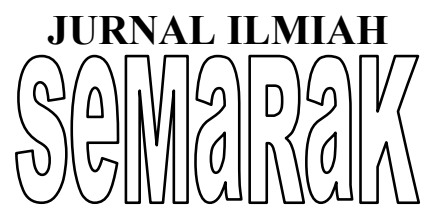

P-ISSN 2615-6849, E-ISSN 2622-3686

Jurnal Semarak,Vol. 1,No.3,Oktober 2018 , Hal (49-61)

@ Prodi Manajemen Fakultas Ekonomi Universitas Pamulang

Resiko Fluktuasi Harga Saham. Kondisi kinerja keuangan perusahaan sangat mempengaruhi fluktuasi harga saham emiten. Apabila kondisi kinerja keuangannya bagus maka sahamnya akan menjadi incaran investor untuk membeli sahamnya sehingga harga sahamnya bergerak naik. Sebaliknya apabila kinerja keuangannya jelek, maka investor pemegang saham emiten tersebut akan cepat-cepat melepaskan portopolio saham emiten tesebut.

Jadi latar belakang penelitian yang penulis lakukan karena terdorong untuk mengetahui tingkat resiko dalam berinvestasi pada saham yang sangat berfluktuasi dalam berbagai kejadian/peristiwa ekonomi. Atau untuk mengetahui tingkat resiko saham selama periode tertentu.

\section{B. Perumusan Masalah}

Dari latar belakang yang telah diuraikan di atas dapat dirumuskan beberapa masalah yang dihadapi oleh investor, yaitu:

Apakah Telkom dan Indosat yang termasuk saham unggulan mempunyai tingkat resiko yang tinggi.

Berapa besar tingkat resiko yang ada pada saham tersebut jika diukur berdasarkan perhitungan Standar Deviasi dikaitkan dengan Indeks Harga Saham Individual (IHSI) ?

Berapa besar tingkat resiko bila menggunakan perhitungan $\operatorname{Beta}(\beta)$ dikaitkan deengan Indeks Harga saham Gabungan (IHSG) dan Harga Saham ?
C. Pembatasan Masalah

Mengingat ruang dan tempat sangat terbatas, maka penulis hanya mengambil 2 saham PT.Telekomunikasi Indonesia, Tbk dan PT. Indosat, Tbk dari 5 emiten sektor Telekomunikasi, dengan cara melakukan analilis tingkat resiko Harga Saham tersebut

di Bursa Efek Indonesia (BEI) dalam 2 periode, yaitu: periode I: Januari 2016 - April

2017(Periode 16 bulan pertama) dan periode II: Mei 2017- Agustus 2018(Periode 16 bulan ke 2, melalui pengumpulan data dari www: IDX.ac.id. Data yang digunakan dalam penelitian ini adalah Data Sekunder IDX Monthly Statistics tahun 2016 Agustus 2018

\section{Tujuan Penelitian}

Penelitian ini dimaksudkan untuk melihat dan mengetahui:

1. Sampai sejauh mana perbedaan tingkat resiko harga saham yang terjadi pada periode I (Januari 2016 - April 2017) dan periode II (Mei 2017- Agustus 2018/Periode terjadinya pelemahan Nilai mata uang Rupiah terhadap Dolar Amerika)

2. Untuk melihat dan mengetahui pola perbandingan tingkat resiko diantara kedua periode tersebut.

\section{E. Manfaat Penelitian}

1. Sebagai salah satu bahan evaluasi bagi para pelaku Pasar Modal, khususnya bagi para Analis/Riset, Manajer Investasi, dalam melakukan analisis tingkat resiko terhadap harga-harga saham yang diperdagangkan di Bursa Efek. 


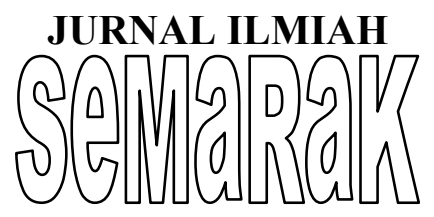

P-ISSN 2615-6849, E-ISSN 2622-3686

Jurnal Semarak,Vol. 1,No.3,Oktober 2018 , Hal (49-61)

@ Prodi Manajemen Fakultas Ekonomi Universitas Pamulang

2. Sebagai bahan evaluasi bagi investor Pasar Modal untuk menilai dan mengukur tingkat resiko tiap-tiap saham yang akan menjadi pilihan investasinya.

\section{II.TINJAUAN PUSTAKA}

\section{A. Investasi Saham}

Investasi dapat diartikan sebagai suatu pengorbanan untuk tidak menggunakan kesempatan membelanjakan uang atau dana sekarang untuk memperoleh suatu kelebihan di kemudian hari.

Kamus Websters menyebutkan investasi sebagai penyisihan uang dengan harapan untuk menghasilkan sesuatu di kemudian hari (Usman Samiadji: 1988, hal. 1)

Investasi dapat dibagi menjadi 3 bagian, yaitu:

Investasi Langsung ( Direct Investment): Lebih banyak bersifat fisik, membutuhkan tenaga kerja, memerlukan enterpreneurship, lebih banyak macamnya, memerlukan banyak administrasi dan perizinan.

2. Investasi Portopolio: Berupa pemilikan portopolio surat berharga(disebut Asset Efek atau Securities Assets), lebih likuid/sewaktu-waktu bisa dialihkan dengan cepat, memerlukan Investment Analyst atau Security Analyst,tidak memerlukan banyak tenaga kerja, tidak memerlukan Enterpreneur.

Selanjutnya investasi dapat didifinisikan sebagai penundaan konsumsi sekarang untuk digunakan di dalam produksi yang efisien selama periode waktu tertentu(Yogiyanto: 1998, hal. 5).Tipe- tipe investasi keuangan terdiri dari (Jogiyanto: 1998, hal. 6)

Investasi Langsung, yaitu pembelian langsung aktiva keuangan suatu perusahaan.

Investasi tidak langsung, yaitu pembelian saham dari perusahaan yang mempunyai portopolio aktiva-aktiva keuangan dari perusahaan-perusahaan lain.

Investasi tidak langsung dilakukan dengan membeli surat-surat berharga dari perusahaan investasi. Perusahaan investasi adalah perusahaan jasa keuangan dengan cara menjual sahamnya kepada publik dan menggunakan dana yang diperoleh untuk diinvestasikan ke dalam portopolionya.

Graham,Dodd dan Cottle dalam bukunya Security Analysis mengatakan investasi harus diidentifikasikan dengan keamanan (safety). Keamanan baru diperoleh

setelah tindakan investasi itu diuji dengan penilaian yang menggunakan standar yang

lazim berlaku dan telah memenuhi standar penilaian tersebut (Danareksa, PT: 1987, hal. 53)

Pengertian saham adalah tanda penyertaan modal pada Perseroan Terbatas

sebagaimana diatur dalam Kitab Undangundang Hukum Dagang (Danareksa, PT: hal. 80). Sedangkan manfaat pemilikan saham meliputi:

Dividen, yaitu bagian dari keuntungan perusahaan yang dibagikan kepada pemilik saham.

Capital Gain, yaitu selisih dari harga jual dengan harga beli, disebut juga 


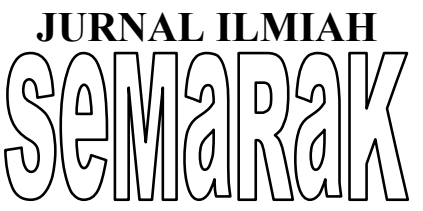

P-ISSN 2615-6849, E-ISSN 2622-3686

Jurnal Semarak,Vol. 1,No.3,Oktober 2018 , Hal (49-61)

@Prodi Manajemen Fakultas Ekonomi Universitas Pamulang

Selisih Kurs, jika pemilik menjual sahamnya dengan kurs yang lebih tinggi dibandingkan dengan kurs pad waktu membelinya.

Saham adalah sebuah surat berharga yang di dalamnya tertulis besarnya kepemilikan terhadap sebuah perusahaan dari sebesar modal perusahaan (Adler Haymans Manurung: 1992, hal. 13)

Yang dimaksud dengan saham adalah penyertaan dalam modal suatu perusahaan.

Dengan demikian seorang pemegang saham pada hakekatnya merupakan pemilik dari suatu perusahaan, dimana dapat disimpulkan bahwa ia turut menikmati

hasil-hasil keuntungan yang diperoleh perusahaan dan turut menanggung kerugian yang diderita perusahaan.

Pengertian lebih rinci dari berbagai jenis saham yang dikenal di Indonesia

(Danareksa,PT, hal. 81) antara lain:

1. Saham Biasa (Ordinary Share), yaitu saham yang tidak memperoleh hak istimewa. Pemegang saham biasa mempunyai hak untuk memperoleh dividen sepanjang perseroaan memperoleh keuntungan dan mempunyai hak suara pada RUPS. Jika terjadi likuidasi perseroan pemilik saham memiliki hak memperoleh sebagian dari kekayaan perseroaan setelah tagihan kreditur dilunasi. Namun itu hak umum, bukan hak istimewa.

2. Saham Bonus (Bonus Share). Perbandingan antara cadangan modal saham yang tidak berimbang pada suatu perseroaan dapat dihilangkan dengan jalan memberikan saham bonus kepada saham dengan Cuma-Cuma. Saham bonus diciptakan dari Pos Cadangan perseroan yang terbentuk dari uang kontan yang tidak dibagikan kepada para pemegang saham. Kekayaan perseroaan tidak mengalami perubahan, karena tidak ada kekayaan yang bertambah dan tidak ada modal yang dibayarkan. Yang berubah adalah perubahan kualitatif dan pergeseran struktur permodalan. Hal ini merupakan kapitalisasi,

akibatnya kurs saham akan turun menyesuaikan dengan perbandingan bonus yang dikeluarkan.

3. Saham Preferen(Prefered Stock). Saham yang memberikan hak untuk mendapatkan dividen atau bagian kekayaan pada saat pembubaran perseroaan lebih dulu dari saham biasa, dan di samping itu mempunyai preferensi untuk mengajukan usul pencalonan Direksi/Komisaris.

Tiga jenis saham ini yang sampai sekarang diperdagangkan di BEI.

\section{B. Resiko dan Keuntungan}

Resiko dapat diartikan sebagai kemungkinan kerugian/kerusakan. Secara kumulatif resiko keuangan dapat diukur dengan melihat distribusi kemungkinan tingkat pendapatan dari suatu investasi. Pendapatan(keuntungan) adalah merupakan sesuatu yang paling penting bagi suatu investasi, tetapi hal ini akan selalu dikaitkan dengan besarnya tingkat resiko yang tidak diketahui oleh para investor. Distribusi kemungkinan yang objektif dapat diukur dengan data-data historis. 
Sedangkan keuntungan dapat diartikan sebagai selisih positif antara nilai beli dengan nilai jual, pada saham disebut “ Capital Gain”. Dibidang Pasar Modal instrument investasi yang mengandung resiko yang lazim dijadikan alat investasi adalah saham, yaitu Saham Biasa. Asset yang mengandung resiko ditandai dengan penerimaan hasil yang tidak tetap besarnya dan mungkin tidak menerima hasil sama sekali, bahkan dapat menderita kerugian yang besar(Capital Loss). Jadi dalam membuat keputusan jual-beli saham maupun menilai kelayakan harga saham seorang investor yang rasional akan mempertimbangkan berbagai aspek ekonomi (Gudono: 1999, hal. 43). Faktor- faktor tersebut meliputi: Kemampuan perusahaan mendapatkan laba, Tingkat Inflasi, Kondisi perekonomian negara pada umumnya, Regulasi Pemerintah dan Kebijakan Direksi.

Pertimbangan dari berbagai aspek tersebut perlu dilakukan oleh investor karena setiap yang dilakukan jelas yang diharapkannya adalah keuntungan.Investasi tersebut tidak lebih dari penanaman modal saat sekarang untuk membeli harapan keuntungan (expected return) yang diperoleh pada masa yang akan datang. Tidak seorangpun yang dapat memastikan bahwa suatu investasi akan memperoleh keuntungan dalam jumlah tertentu pada masa mendatang.

Dalam teori Keuangan Modern (The Modern Theory of Finance) berusaha menjelaskan Variabel Keuntungan dengan $\mathrm{m}$ enggunakan konsep Probabilitas(Awat Napa: 1999, hal. 10). Penggunaan konsep Probabilitas ini dianggap tepat karena sering terjadi deviasi antara keuntungan yang diharapkan dan kkeuntungan yang diperoleh. Dalam konsep ini keuntungan yang diharapkan (expected return) merupakan nilai keuntungan rata-rata yang dihitung atas dasar probabilitas tertentu. Dalam tulisan ini resiko yang ada menunjukkan variabilitas dari keuntungan yang diharapkan yang melekat dalam situasi investasi.

\section{Teori Pergerakan Harga Saham}

a. Indeks Harga Saham Individual(IHSI)

Indeks Harga saham Individual adalah merupakan ukuran dari pergerakan harga saham yang diperdagangkan di Pasar Reguler yang digunakan untuk melihat trend perkembangan suatu saham secara individu.

Rumus perhitungan IHSI $=\underline{\text { Reguler }}$ Closing Price x 100

Base Price
Base Price $=$ Harga Perdana/ Harga setelah Stock Split

b. Indeks Harga Saham Gabungan (IHSG).

Indeks Harga Saham Gabungan merupakan tolak ukur dari pergerakan harga saham secara keseluruhan yang diperdagangkan di Pasar Reguler. Tujuannya untuk melihat trend perkembangan harga-harga saham, yang sangat berguna bagi investor dalam menentukan investasinya. Faktor-faktor yang menjadi penyebab IHSG naik/turun antara lain: Keadaan ekonomi, situasi politik, keadaan meneter, kebijakan-kebijakan 


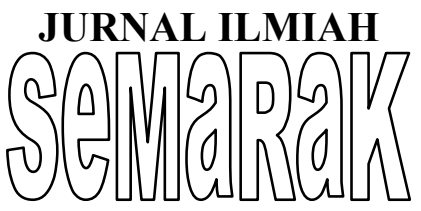

P-ISSN 2615-6849, E-ISSN 2622-3686

Jurnal Semarak,Vol. 1,No.3,Oktober 2018 , Hal (49-61)

@ Prodi Manajemen Fakultas Ekonomi Universitas Pamulang

ekonomi, dan keamanan. Faktor-faktor tersebut sangat berpengaruh terhadap kondisi perusahaan- perusahaan yang ada yang memiliki Resiko Sistimatis yang berbeda-beda.

Rumus Perhitungan IHSG $=\Sigma$ (Reguler Closing Price $\mathrm{x}$ Number of Share $\mathrm{x}$ 100

Base Value

Base Value $=\Sigma($ Base Price $\mathrm{x}$ Number of Shares)

\section{Hubungan antar Variabel Yang Digunakan}

Berdasarkan rumusan permasalahan yang telah dikemukakan sebelumnya, maka untuk melihat hubungan antar variabel yang digunakan dalam penilaian tingkat resiko saham yaitu:

1. Untuk pengukuran tingkat resiko Standar Deviasi (Variabel Dependen) sebagai variabel independennya adalah Indeks Harga Saham Individual (IHSI).

2. Untuk pengukuran tingkat resiko dengan Beta ( $\beta$ ) saham (Variabel Dependen) sebagai variabel independennya adalah Indeks Harga Saham Gabungan (IHSG) dan Harga Saham Penutupan Akhir Bulan.

\section{E. Hipotesis}

Dari rumusan permasalahan dan landasan teori yang telah diuraikan sebelumnya, maka dapat dirumuskan hipotesis sebagai berikut:
1. Saham Unggulan mempunyai tingkat resiko yang tinggi pada saat terjadinya gejolak nilai mata uang rupiah, karena harga saham cenderung mengalami penurunan yang cukup signifikan.

2. Jika harga saham unggulan mengalami penurunan harga secara drastis, maka Indeks Harga Saham Gabungan (IHSG) akan mengalami penurunan secara drastis pula.

Jika menggunakan perhitungan tingkat resiko dengan Standar Deviasi, terdapat dimana selisih perbedaan antara IHSI yang satu dengan yang lainnya besar, maka berarti tingkat resiko saham tersebut tinggi. Sedangkan jika makin kecil Standar Deviasi makin rapat distribusi probabilitas maka makin kecil tingkat resiko suatu saham.

Saham Unggulan memiliki hubungan linear antara Indeks Harga Saham Gabungan (IHSG) dengan Harga Saham. Pada masa terjadinya gejolak moneter, IHSG mengalami penurunan secara drastis maka harga saham unggulan mengalami penurunan. Begitu juga sebaliknya jika IHSG naik, maka harga saham unggulan naik.

Jika mnggunakan perhitungan tingkat resiko dengan Beta ( $\beta$ ) saham, maka tingkat resiko saham tersebut tinggi, karena harga saham tersebut mempunyai kesensitifan yang tinggi terhadap IHSG.

\section{METODE PENELITIAN DAN PENGUMPULAN DATA}

\section{A. Metode Penelitian yang digunakan}

Penulis melakukan penelitian mengenai Tingkat Resiko terhadap harga Saham 


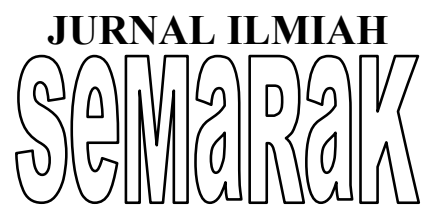

P-ISSN 2615-6849, E-ISSN 2622-3686

Jurnal Semarak,Vol. 1,No.3,Oktober 2018 , Hal (49-61)

@Prodi Manajemen Fakultas Ekonomi Universitas Pamulang

Unggulan PT. Telekomunikasi Indonesia, Tbk dan PT. Indosat, Tbk periode Januari

2016 -Aguatus 2018, yang dibagi menjadi 2 (dua) periode:

Periode Januari 2016 - April 2017, untuk mengetahui tinggi- rendahnya tingkat resiko harga saham tersebut sebagai dampak peristiwa yang terjadi pada periode tersebut.

Periode Mei 2017 - Agustus 2018 ,untuk mengetahui tinggi rendahnya harga saham teersebut sebagai dampak peristiwa yang terjadi selama periode tersebut, diantaranya dampak melemahnya nilai tukar rupiah terhadap mata uang asing khususnya terhadap Dollar Amerika.

Penelitian ini dilakukan dengan maksud untuk mengetahui berapa besar

TingkatResiko saham tersebut. Di dalam menganalisis ada 2(dua) tahap penilaian yang penulis lakukan, yaitu:

1. Analisis Tingkat Resiko dengan Standar Deviasi.

2. Analisis Tingkat Resiko dengan Beta ( $\beta$ ) Saham

Dipilihnya saham Telkom dan Indosat berdasarkan pertimbangan:

1. Masuk dalam rangking 45 saham berkapitalisasi pasar terbesar.

2. Aktif diperdagangkan di Pasar Reguler (Liquid) dan sangat berfluktuasi.

3. Telah tercatat/Listing sejak tahun $1994-1995$.

4. Keadaan keuangan perusahaan dan prospek pertumbuhannya sangat baik.
5. Pengaruhnya cukup besar terhadap kenaikan/penurunan IHSG.

\section{B. Teknik Pengumpulan Data}

Data yang digunakan dalam penelitian ini adalah Data Sekunder yang diambil dari webside: IDX.ac.id Bursa Efek Indonesia berdasarkan IDX MONTHLY STATISTICS dari tahun 2016 - Agustus 2018 serta mempelajari literatur-literatur yang berhubungan dengan penelitian, guna memperoleh data informasi keuangan untuk digunakan sebagai dasar mengukur tingkat resiko. Dari sumber tersebut diperoleh data-data: harga-harga saham, Indeks Harga Saham Individual(IHSI), Indeks Harga Saham Gabungan (IHSG) dan data-data lainnya yang berkaitan dengan penelitian ini.

\section{Teknik Analisis Data dan Langkah- langkahnya}

Teknik analisis yang digunakan untuk memperoleh penjelasan tentang Tingkat

Resiko, dilakukan dengan pengujian statistik untuk membuktikan hipotesis yang telah dirumuskan. Alat ukur yang digunakan dalam pengujian statistik terhadap tingkat resiko yang ada pada saham tersebut dilakukan dengan langkah-langkah sebagai berikut:

Menghitung Standar Deviasi dengan variabel independennya Indeks Harga Saham Individual(IHSI) penutupan akhir bulan.

Menghitung Beta $(\beta)$ saham dengan variabel independennya Indeks Harga Saham Gabungan(IHSG) penutupan akhir bulan dan harga saham penutupan akhir bulan. 


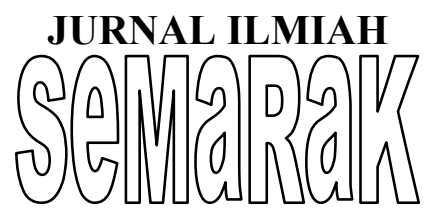

P-ISSN 2615-6849, E-ISSN 2622-3686

Jurnal Semarak,Vol. 1,No.3,Oktober 2018 , Hal (49-61)

@Prodi Manajemen Fakultas Ekonomi Universitas Pamulang

Rumus perhitungan Standar Deviasi : $\mathrm{SD}=$ $\underline{\sqrt{(\Sigma(X-\bar{X}})^{2}}$

$$
n-1
$$

dimana $: X=$ Nilai Populasi (IHSI)

$$
\bar{X}=\text { Nilai rata-rata dari }
$$

jumlah seluruh populasi

$$
\mathrm{n}=\text { Jumlah populasi }
$$

Rumus Perhitungan Beta $(\beta)$ saham: Covariance (Rm.Rj)

Variance (Rm)

Keterangan: Covariance $(\mathrm{Rm} \cdot \mathrm{Rj})=(\mathrm{Rm}$ - rm) $(\mathrm{Rj}-\mathrm{rj})$

$-\mathrm{rm})^{2}$

$$
\operatorname{Variance}(\mathrm{Rm}) \quad=\underline{\Sigma(\mathrm{Rm}}
$$

$$
\begin{aligned}
& \mathrm{n}-1 \\
& \text { dimana }: \text { Rm }=\text { Balikan IHSG } \rightarrow(\text { IHSG } \\
& \text { 1- IHSG 0 : IHSG 0, dst } \\
& \text { Rj }=\text { Balikan Harga Saham } \rightarrow \\
& (\text { Harg -Harga 0) : Harga 0, } \\
& (\text { Harga 2-Harga 1) : Harga 1, dst. } \\
& \text { rm }=\text { Rata-rata balikan IHSG } \\
& \text { Rm) } \quad \text { rj } \quad \text { Rata-rata balikan Harga } \\
& \text { Saham (Rj) }
\end{aligned}
$$

\section{HASIL ANALISIS DATA DAN PEMBAHASAN PENELITIAN}

\section{A. Analisis Tingkat Resiko Harga Saham dengan Standar Deviasi}

1. PT. Telekomunikasi Indonesia, Tbk

Pada Periode I (Januari 2016 - April 2017) IHSI Telkom mengalami kenaikan hingga mencapai level penutupan terti nggi pada April 2017: 2,296.555.Sedangkan

Level terendah sebelumnya terjadi Pebruari 2016: 1,708.009,-, naik 34,46\%

Hasil perhitungan tingkat resiko dengan Standar Deviasi $=185,903$

Koefisien Variasi $=9,114 \%$

Pada Periode II (Mei 2017 - Agustus 2018) IHSI Telkom berbalik mengalami penurunan hingga mencapai level terendah Agustus 2018: 1,834.139,- dan tertinggi pada Juli-Agustus 2017: 2,464.724 turun 25,58\%. Hasil perhitungan tingkat resiko dengan Standar Deviasi $=221,794$. Koefisien Variasi $=$ 10,365\% (Lihat Tabel- 5: Perhitungan Standar Deviasi Telkom, hal: 15)

2. PT. Indosat, Tbk

Pada Periode I (Januari 2016 - April 2017) IHSI Indosat mengalami kenaikan hingga mencapai level penuutupan tertinggi pada April 2017: 512,500. Sedangkan level terendah terjadi Pebruari 2016: 369,643 , naik $38,65 \%$ 


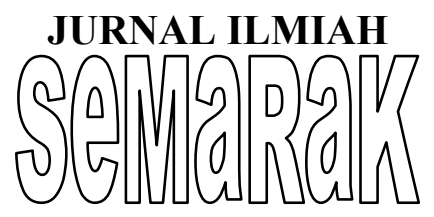

P-ISSN 2615-6849, E-ISSN 2622-3686

Jurnal Semarak,Vol. 1,No.3,Oktober 2018 , Hal (49-61)

@ Prodi Manajemen Fakultas Ekonomi Universitas Pamulang

Hasil perhitungan tingkat resiko dengan Standar Deviasi=37,459

Koefisien Variasi $=8,17 \% \%$

Pada Periode II (Mei 2017 - Agustus 2018) IHSI Indosat berbalik mengalami penurunan secara terus-menerus hingga mencapai level terendah terjadiAgustus 2018: 231,429 dan tertinggi bulan Mei 2017: 483,929,- , turun 52,18\%.

Hasil perhitungan tingkat resiko denga n Standar Deviasi $=83,546$.

Koefisien Variasi $=22,96 \%$ (Lihat

Tabel - 6: Perhitungan Standar Deviasi Indosat, hal: 16).

\section{B. Analisa Tingkat Resiko Harga Saham dengan Beta ( $\beta$ ) Saham}

1. PT. Telekomunikasi Indonesia, Tbk

Pada periode I(Januari 2016 - April 2017) IHSG mengalami kenaikan hingga level penutupan tertinggi pada April 2017 : 5,685.298. Sedangkan level terendah terjadi Januari 2018: 4,615.163, naik 23,19\%. Harga saham Telkom naik secara terus menerus mencapai level tertinggi April 2018 dengan penutupan kurs Rp. 4.370,-. Sedangkan level terendah Rp. 3,250,- Februari 2016, naik 34,46\%

Pada Periode II (Mei 2017 - Agustus 2018) IHSG berfluktuasi dengan level penutupan tertinggi Januari 2018: 6,605,631 dan terendah pada bulan Mei 2017: 5,738.155, naik $15,12 \%$.Sementara harga saham Telkom justru mengalami penurunan secara terus menerus, dari harga penutupan tertinggi Rp. 4,690,- pada Juli-Agustus 2017 turun sampai mencapai harga penutupan terendah Rp. 3.490,- bulan Agustus 2018.turun $25,57 \%$.

Hasil Perhitungan tingkat resiko dengan Beta ( $\beta$ ) saham:

Periode I (Januari 2016 - April 2017) Beta $(\beta)$ saham $=0,33$.

Periode II (Mei 2017 - Agustus 2018) $\operatorname{Beta}(\beta)$ saham $=0,02$

Dari hasil perhitungan tingkat resiko dengan Beta $(\beta)$ : tingkat resiko saham Telkom pada kedua periode tersebut cukup rendah, karena Beta $(\beta)$ saham $<1$.

(Lihat Tabel - 7: Perhitungan Beta saham PT. Telkom, hal: 18)

\section{PT. Indosat, Tbk}

Pada periode I(Januari 2016 - April 2017) dengan kenaikan IHSG, sama dengan

Telkom, harga saham Indosat mengalami kenaikan secara terus menerus mencapai level tertinggi April 2018 dengan penutupan kurs Rp. 7.175,--

Sedangkan level terendah Rp.5,175,bulan Februari 2016, naik 38,65\%.

Pada Periode II (Mei 2017 - Agustus 2018) IHSG berfluktuasi sama dengan Telkom dengan harga saham Indosat justru mengalami penurunan secara terus menerus, dari harga penutupan tertinggi Rp. 6.775,- bulan 2017 turun sampai mencapai harga penutupan terendah Rp. 3.180,- bulan Juni 2018, turun 53,06\%.

Hasil Perhitungan tingkat resiko dengan Beta $(\beta)$ saham: 
Periode I (Januari 2016 - April 2017) Beta $(\beta)$ saham $=-0,67$.

Periode II (Mei 2017 - Agustus 2018) Beta $(\beta)$ saham $=1,44$

Dari hasil perhitungan tingkat resiko dengan Beta $(\beta)$ : tingkat resiko saham Indosat pada periode I tersebut cukup rendah, karena Beta $(\beta)$ saham $<-1$. Sedangkan pada

Periode II justru berbalik ke tingkat resiko yang tinggi, karena perubahan Beta $(\beta)$ saham $>1$. (Lihat Tabel -8: Perhitungan Beta Saham PT. Indosat, hal: 19)

Tabel - 1

\section{HASIL PERHITUNGAN TINGKAT}

\section{RESIKO}

\begin{tabular}{|l|l|l|l|l|l|l|l|l|}
\hline \multirow{2}{*}{ No. } & \multirow{2}{*}{ Saham } & \multirow{2}{*}{ Kode } & \multicolumn{2}{|c|}{$\begin{array}{l}\text { Standar } \\
\text { Deviasi }\end{array}$} & \multicolumn{2}{|c|}{$\begin{array}{l}\text { Koefisien } \\
\text { Variasi }\end{array}$} & \multicolumn{2}{c|}{$\begin{array}{l}\text { Beta } \\
\text { Saham }\end{array}$} \\
\cline { 4 - 9 } & & & $\begin{array}{l}\text { Periode } \\
\text { I }\end{array}$ & $\begin{array}{l}\text { Periode } \\
\text { II }\end{array}$ & $\begin{array}{l}\text { Peiode } \\
\text { I }\end{array}$ & $\begin{array}{l}\text { Periode } \\
\text { II }\end{array}$ & $\begin{array}{l}\text { Peiode } \\
\text { I }\end{array}$ & $\begin{array}{l}\text { Periode } \\
\text { II }\end{array}$ \\
\hline 1 & Telkom & TLKM & 185,903 & 221,794 & $9,11 \%$ & $10,37 \%$ & 0,33 & 0,02 \\
\hline 2 & Indosat & ISAT & 37,459 & 83,546 & $8,17 \%$ & $22,96 \%$ & 0,67 & 1,44 \\
\hline
\end{tabular}

Sebagai interplasi terhadap resiko atas saham unggulan berdasarkan perhitungan $\operatorname{Beta}(\beta)$ saham sebagai berikut:

Angka $\operatorname{Beta}(\beta)$ yang tinggi berarti menunjukkan sangat pekanya pengaruh perubahan pasar terhadap perubahan harga saham individu. Oleh karena itu dalam situasi pasar yang "bearish" saham yang berkoefisien yang rendah akan lebih aman bagi investor dalam berinvestasi dibandingkan dengan saham-saham yang berkoefisien yang tinggi.

Resiko adalah merupakan suatu ketidakpastian tentang nilai-nilai yang diharapkan, yang mana setelah dilakukan analisis tingkat resiko dengan $\operatorname{Beta}(\beta)$ atas saham unggulan Telkom dan Indosat dapat disimpulkan bahwa kenaikan/penurunan IHSG sangat dipengaruhi oleh kenaikan/penurunan dari harga saham tersebut. 


\section{KESIMPULAN DAN SARAN}

\section{A. Kesimpulan}

1. Perhitungan Tingkat Resiko dengan Standar Deviasi

Dari hasil analisis terhadap saham unggulan tersebut dengan menggunakan Standar Deviasi berdasarkan variabel iendependen IHSI, maka tingkat resiko harga saham Periode I mempunyai tingkat resiko yang lebih rendah dibandingkan dibandingkan Periode II

Dari kedua saham unggulan tersebut dengan menggunakan Standar Deviasi pada periode I saham Telkom mempunyai tingkat resiko lebih tinggi dibandingkan Indosat denggan Koefisien Variasi $=9,11 \%$. Sedangkan Indosat KoefisienVariasi $=8,17 \%$. Periode II saham yang mempunyai tingkat resiko yang tinggi Indosat dengan Koefisien Variasi = 22,96\%. Sedangkan Telkom dengan Koefisien Variasi $=10,37 \%$.

2. Perhitungan Tingkat Resiko dengan Beta $(\beta)$

a. Tingginya angka $\operatorname{Beta}(\beta)$ menunjukkan sangat pekanya pengaruh perubahan pasar terhadap perubahan harga saham individual. Dalam kondisi bearish saham yang mempunyai Koefisien $\operatorname{Beta}(\beta)$ yang rendah akan lebih aman dan menguntungkan bagi investor dari pada saham yang mempunyai Koefisien $\operatorname{Beta}(\beta)$ yang tinggi.

b. Resiko adalah merupakan suatu ketidakpastian tentang harga-harga saham yang akan terjadi, setelah dilakukan analisis dengan menggunakan $\operatorname{Beta}(\beta)$ maka dapat diambil kesimpulan IHSG sangat mempengaruhi harga-harga saham. Pada Periode I dari ke 2 saham tersebut mempunyai tingkat kesensitifan yang atas IHSG dengan $\operatorname{Beta}(\beta)$ saham $<1$, Telkom $=$ 0,33 dan Indosat $=-0,67$

c. Pada Periode II adalah masa terjadi melemahnya nilai tukar Rupiah terhadap Dolar Amerika hingga mencapai Rp. 15,000,- sehingga sangat pengaruh terhadap harga-harga saham dan IHSG

BEI. Dari ke 2 saham tersebut, Indosat mempunyai tingkat kesentitifan yang tinggi atas IHSG dimana $\operatorname{Beta}(\beta)$ saham > 1 yaitu: 1,44. Sedangkan saham Telkom justru mempunyai Beta $(\beta)$ saham < 1 yang lebih rendah dari Periode I, yaitu: 0,02 . Ini artinya pelemahan nilai tukar Rupiah terhadap Dolar Amerika tidak terlalu berpengaruh terhadap tingkat resiko sahamTelkom.

\section{B. S a r a n}

1. Selaku investor di Pasar Modal harus berhati-hati dalam memilih saham yang akan dibeli, jangan sampai membeli saham seperti membeli kucing dalam karung, dalam arti tidak tahu sama sekali tentang situasi dan kondisi perkembangan perusahaannya, khususnya masalah keadaan keuangannya demi untuk menghindari resiko terburuk antara lain seperti terjadi delisting karena perusahaan bangkrut.

2. Investor sudah selayaknya dapat menghitung tingkat resiko terhadap hargaharga saham yang terjadi di bursa, sehingga tahu apakah harga suatu saham sudah terlalu tinggi atau masih layak untuk dibeli, demi 


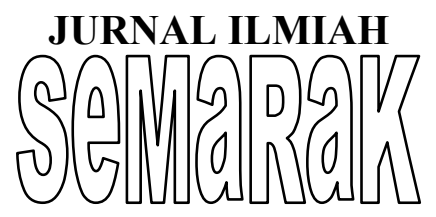

P-ISSN 2615-6849, E-ISSN 2622-3686

Jurnal Semarak,Vol. 1,No.3,Oktober 2018 , Hal (49-61)

@ Prodi Manajemen Fakultas Ekonomi Universitas Pamulang

untuk menghindari resiko kerugian yang besar akibat penurunan harga yang tajam.

3. Pihak Bursa Efek perlu memperluas publikasi yang secara rutin tentang data atas perusahaan Go Publik yang sahamnya tercatat di bursa guna untuk memudahkan investor dalam mendapatkan data dan informasi serta sebagai bahan untuk membuat analisis bagi investor.

4. Pihak Bursa Efek atau pihak-pihak yang terkait dalam kegiatan di Pasar Modal supaya lebih menggalakkan lagi sosialisasi tentang Bursa ke seluruh lapisan masyarakat, guna menarik investor sebanyak-banyak di bidang industri Pasar Modal.

\section{DAFTAR PUSTAKA}

Adler Haymans Manurung, Analisis Saham Indonesia, Jakarta, Economic Student 1992'

Agus Sartono, R, Drs, MBA, Manajemen Keuangan, Yogyakarta,BPFE 1994.

Awat Napa. J, Manajemen

Keuangan(Pendekatan Matematis), Jakarta, Gramedia Pustaka Utama 1999'

Bursa Efek Indonesia, IDX - Monthly Statistics Januari 2016 - Agustus 2018, Research \& Development Divisions.

Danareksa, PT, Pasar Modal Indonesia Pengalaman dan Tantangan, Jakarta, Lembaga Penerbit FEUI 1987.
Gudono, Majalah Kelola, No. 20/VIII/1999

Jogiyanto HM, Dr, MBA, Akt, Teori Portopolio dan Analisis Investasi, Yogyakarta, BPFE 1998.

Saiful M. Ruky, S.E, MBA, Menilai Penyertaan dalam Perusahaan, Jakarta, Gramedia Pustaka Utama, 1999.

Usman Samiadji, Pengenalan Investasi, Jakarta, Diklat Kursus Pasar ModaL 
JURNAL

(2) 0 a
P-ISSN 2615-6849 E-ISSN 2622-3686

Semarak,Vol. 1, No.3,Oktober 2018, Hal (1-20)

@Prodi Manajemen Fakultas Ekonomi Universitas Pamulang 